\title{
Humanitarian intervention
} in the long nineteenth century

Setting the precedent

\section{Alexis Heraclides and Ada Dialla}




\section{Humanitarian intervention in the long nineteenth century}

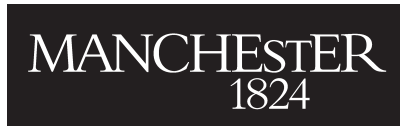

Manchester University Press 


\section{HUMANITARIANISM Key debates and new approaches}

This series offers a new interdisciplinary reflection on one of the most important and yet understudied areas in history, politics and cultural practices: humanitarian aid and its responses to crises and conflicts. The series seeks to define afresh the boundaries and methodologies applied to the study of humanitarian relief and so-called 'humanitarian events'. The series includes monographs and carefully selected thematic edited collections which will cross disciplinary boundaries and bring fresh perspectives to the historical, political and cultural understanding of the rationale and impact of humanitarian relief work.

Calculating compassion: Humanity and relief in war, Britain 1870-1914

Rebecca Gill 


\section{Humanitarian intervention in the long nineteenth century}

Setting the precedent

Alexis Heraclides and Ada Dialla

Manchester University Press 


\section{Copyright (@) Alexis Heraclides and Ada Dialla 2015}

The rights of Alexis Heraclides and Ada Dialla to be identified as the authors of this work have been asserted by them in accordance with the Copyright, Designs and Patents Act 1988.

Published by Manchester University Press

Altrincham Street, Manchester M1 7JA

www.manchesteruniversitypress.co.uk

British Library Cataloguing-in-Publication Data

A catalogue record for this book is available from the British Library

Library of Congress Cataloging-in-Publication Data applied for

ISBN 9780719089909 hardback

First published 2015

The publisher has no responsibility for the persistence or accuracy of URLs for any external or third-party internet websites referred to in this book, and does not guarantee that any content on such websites is, or will remain, accurate or appropriate.

Typeset in Arno and Univers by R. J. Footring Ltd, Derby 